\title{
SOBRE A INVESTIGAÇÃO ARTÍSTICA E O DESCONFINAMENTO DO SABER'
}

ABOUT ARTISTIC RESEARCH AND THE

DECONFINEMENT OF KNOWLEDGE

Fábio Waki

ORCID 0000-0003-2902-6231

Universidade de Coimbra, Coimbra, Portugal

Embora a investigação artística seja hoje um dos temas mais promissores de pesquisa nas humanidades do meio acadêmico europeu, sua formalização como programa de pós-graduação ao longo do Processo de Bolonha não ocorreu sem levantar consigo uma série de polêmicas - bastante diversas, mas que gravitam em torno de uma antinomia maior: o fato de que, por mais que estudos em investigação artística tendam a confiar em práticas artísticas como meios para se alcançar novas formas de pensar, saber, ver, ouvir, dizer, agir, sentir e viver no presente, eles ainda tendem a ser regulados pelos interesses teleológicos e econômicos das instituiçôes onde são conduzidos.

Isto é, embora o principal objetivo da investigação artística seja encontrar maneiras de se conhecer o mundo que fujam de uma ortodoxia de pensamento pautada nos proveitos de uma razáo epistemológica e de uma intençấo capitalista, na prática sua legitimidade ainda tende a ser avaliada pelo poder institucional dessa mesma ortodoxia, a qual acaba por tomar como legítimas apenas aquelas investigaçóes que, submetidas ao exame de uma razão epistemológica, deixem transparecer, direta ou indiretamente, algum potencial ao lucro.

Claro, esse impasse está longe de ser resolvido, mas a sua existência, justamente, tem permitido à investigação artística colocar em xeque uma questão fundamental sobre a natureza do sujeito em sua relação com o mundo: de um lado, a obsolescência de uma antiga Bildung, eurocêntrica, burguesa e patriarcal, embasada na ideia de que só são válidos aqueles saberes alcançados por meio do isolamento, da introspecçáo e da capacidade de abstração do indivíduo; de outro, a emergência de uma nova Bildung, sempre o mais inclusiva possível, embasada na ideia de que são igualmente ou até mais válidos aqueles saberes alcançados por meio de uma coletividade, em

1 Resenha de: POLANCO, Aurora Fernández. Critica Visual del Saber Solitario. Bilbao: Consonni, 2019, 288 p. Utilizo aqui a versão em ebook; os números de páginas referem-se a essa versão. 
particular uma que tome em conta experiências práticas e conhecimentos tácitos por parte do indivíduo.

O livro Crítica Visual del Saber Solitario, de Aurora Fernández Polanco, professora de história da arte na Universidade Complutense de Madri, trata exatamente desse processo de obsolescência e emergência.

Inspirado em "O Ensaio como Forma", de Theodor Adorno, e no Projeto Arcadas, de Walter Benjamin, ${ }^{2}$ seu livro é uma coletânea de ensaios que tomam imagens como "filosofemas" para análises que, embora independentes umas das outras, se conectam genealogicamente de modo a trazer à luz bases para uma disputa central: uma defesa da investigação artística como prática acadêmica para se desafiar a cada vez mais obsoleta ideia de que uma Bildung só é legítima quando o indivíduo a trabalha na solidão do seu espaço privado e por meio da suposta pureza da sua autossuficiência, isto é, por meio de um estado de isolamento, introspecção e abstração que o separa, física e espiritualmente, do caos que, para ele, reina no mundo exterior.

Polanco divide seu livro em três seçóes que sintetizam sua defesa:

Em "Tese", a mais complexa das seções, ela examina uma série de documentos do século XVIII - em particular retratos de filósofos trabalhando em seus escritórios - para confirmar como a ideia de Bildung que viria a servir de base às nossas concepçóes de conhecimento e experiência estética estava em grande medida fundamentada em uma noção de autorrealização individual que era, na verdade, uma busca por um privilégio burguês. Para esses filósofos - homens brancos e muitas vezes abastados -, a legitimidade de um conhecimento e de uma experiência estética dependia de que o indivíduo se retirasse da sociedade, a fim de que esse conhecimento pudesse ser alcançado na sua forma mais profunda de razão pura e essa experiência pudesse ser alcançada na sua forma mais profunda de prazer puro. Segundo Polanco, não é nenhuma coincidência, portanto, que pinturas que retratam esses filósofos trabalhando em geral o fazem de modo a enfatizar a capacidade que eles tinham de se abstrair da realidade material quando no conforto dos seus aposentos - o que verificamos, por exemplo, nas imagens em que eles se debruçam absortos sobre seus escritos ou nas imagens em que se deixam divagar a seus mais elevados pensamentos em busca de alguma verdade; ao mesmo tempo, tampouco é coincidência que as pinturas que retratam as mulheres dessa época o fazem de modo a enfatizar suas subordinaçóes a seus ambientes privados - o que verificamos, por exemplo, nas imagens que as retratam em meio às obrigaçóes do lar ou nas imagens que registram seus momentos de ócio, como o hábito que tinham de observar o mundo exterior a partir dos limites dos seus lares. No entanto, a ideia mais fundamental a se

2 A influência de Adorno e de Benjamin sobre Polanco pode ser verificada em outras publicações suas. Ver POLANCO, 2013 e POLANCO, 2015. 
aprender do argumento de Polanco nessa primeira seção é, creio, o fato de que, para esses filósofos, para esses homens solitários, até mesmo o mais puro prazer deveria ser em algum momento examinado sob o prisma da mais pura razão, a fim de que sua legitimidade fosse garantida. Ela escreve:

Siglo de las luces: progreso y fe en la razón. En medio de todo ello, también el XVIII es el siglo de la estética que nace como "discurso del cuerpo". Parece ser que no servía cualquier cuerpo, y tampoco valía cualquier experiencia sensorial. Estamos hablando de gusto y sensibilidad, es decir, de sensación educada: la música, la pintura, el viaje, los paseos por el campo o el vino de Burdeos componen el centro del ojo del huracán desde donde las clases ociosas se resguardan y organizan el mundo a través de la educación racional del deseo. (POLANCO, 2019, p. 17)

[Século das Luzes: progresso e fé na razão. Em meio a tudo isso, o século XVIII é também o século da estética que nasce como "discurso do corpo". Parece que não servia qualquer corpo, e tampouco valia qualquer experiência sensorial. Estamos falando de gosto e sensibilidade, isto é, de sensação educada: a música, a pintura, a viagem, os passeios pelo campo e o vinho de Bordeaux compóem o centro do olho do furacáo onde as classes ociosas se abrigam e de onde organizam o mundo através da educação racional do desejo.]

Em "Crise", a mais breve das seçóes e aquela em que sugere uma transição dessa Bildung privada e individualista para uma Bildung pública e coletivista, Polanco examina uma série de documentos visuais do fim dos anos 1960 - em particular imagens de reverberaçóes dos protestos estudantis de 1968 - para confirmar não apenas como a velha ideia de Bildung ainda parecia assombrar o pensamento das universidades da época, mas também como esse pensamento vinha sendo sistematicamente forçado pelos estudantes a encarar sua própria obsolescência. Uma das imagens mais notáveis dessa seção é, sem dúvida, um registro fotográfico do incidente que ficou conhecido como Busenattentat (Atentado dos Seios), uma intervenção organizada por estudantes mulheres na Universidade de Frankfurt em 1969: com os seios nus, elas ocuparam pacificamente uma das aulas regulares de Theodor Adorno nessa universidade, buscando com isso questionar, dentre outros problemas, a eficiência de uma crítica social que, apesar de desenvolvida à luz de um pensamento marxista e como reaçáo às catástrofes de duas recentes guerras mundiais, ainda era regulada por uma epistemologia claramente patriarcal. Ou seja, ao tomar essa imagem como "filosofema", Polanco busca nos mostrar um efetivo momento de contradição histórico-epistemológica: por mais que a teoria crítica de Adorno tivesse como um dos seus objetivos principais colocar em xeque a legitimidade de um pensamento burguês para o bem-estar social, 
ela própria ainda era assombrada por uma Bildung burguesa, a qual tendia a relevar o papel das mulheres na formaçáo do conhecimento justamente por ser solidária, ainda, das "cores cinzas" de um saber por isolamento, introspecção e abstração, e por ser avessa, assim, às "cores vivas" de um saber por coletividade, experiências práticas e conhecimentos tácitos.

Polanco escreve sobre o impacto dessas tensóes na sociedade:

Cuenta Michel De Certeau que, en el fragor del Mayo parisino, una joven ascensorista de los almacenes La Samaritaine respondía titubeante a las preguntas de un periodista: "No sé qué decir, yo no tengo cultura". Un camarada huelguista la interrumpe: "No digas eso. El conocimiento terminó. La cultura de hoy consiste en hablar". Tomar la palabra, lo que no significa tomar el poder, dice De Certeau, se había convertido en un lugar simbólico: en Mayo se tomaba la palabra como se tomó la Bastilla en 1789. (POLANCO, 2019, p.106-107)

[Conta Michel De Certeau que, no fragor do Maio parisiense, uma jovem ascensorista dos armazéns da Samaritaine respondia titubeante às questôes de um jornalista: "Não sei o que dizer, não tenho cultura". Um colega grevista a interrompe: "Náo diga isso. O conhecimento acabou. A cultura de hoje consiste em falar". Tomar a palavra, o que não significa tomar o poder, diz De Certeau, havia se convertido em um lugar simbólico: em Maio se tomava a palavra assim como em 1789 se tomou a Bastilha.]

Em "Caosmose", uma seção bastante autobiográfica, Polanco examina imagens de vários casos de investigação artística - conduzidos na Universidade Complutense de Madri e em outras instituições - em contraposição a imagens relacionadas às "Revoluções de 2011" - como a Primavera Árabe, o Occupy Wall Street e suas reverberaçóes - para confirmar como uma concepção eficiente de Bildung hoje parece ser, de fato, uma que se oriente por uma ideia de coletividade e que busque trabalhar sobre si mesma por meio de experiências práticas e de aplicaçôes de conhecimentos tácitos. Com base nessas imagens, a hipótese de Polanco é a de que essas manifestações, em grande medida confluências entre interesses individuais e coletivos, privados e públicos, intelectuais e comuns à toda a sociedade, mostram como o nosso presente parece ser um em que formas de saber efetivas já não derivam mais de uma reclusão do pensamento a uma esfera privada, mas sim de sua confraternização nos espaços públicos. Essa hipótese, por sua vez, parece incumbir duas responsabilidades à prática acadêmica de investigação artística: a primeira é a de que investigaçóes artísticas devem encorajar os artistas pesquisadores a conduzirem seus estudos por meio de deslocamentos para fora das salas de aula e para longe das velhas liçóes expositivas que caracterizam esses espaços; 
a segunda, intrínseca à primeira, é a de que investigaçóes artísticas devem sempre buscar ser elas mesmas alguma forma daquilo que Hito Steyerl denomina "estética de resistência", isto é, alguma forma de prática artística cujos conteúdos estéticos e epistemológicos sirvam ao maior número possível de pessoas como mediaçóes a críticas sociais sobre os estados presentes das coisas, em particular sobre as relaçóes de poder que configuram as realidades materiais dessas pessoas.

Ela resume sobre os procedimentos de uma investigação artística:

[Una] insistencia en los haceres, pero, como decía, desde una estructura de trabajo en común, porque la gente estaba harta de la obsesiva competencia y la preparación para un conocimiento de mercado, harta de una universidad que elimina el placer del experimento y solo coloniza las mentes y los cuerpos "para el patriarcado y sus saberes encajonados, no para el saber y, mucho menos, para la crítica de las formas de saber”. Y aún más, una ejercitación para el compartir y salir de la fantasía del sujeto autónomo que, en el caso de las facultades de arte, se traviste en la siniestra y cansina metáfora masculina del Genio. (POLANCO, 2019, p.146)

[[Uma] insistência nos fazeres, mas, como dizia, a partir de uma estrutura de trabalho em comum, porque as pessoas estavam fartas da competência obsessiva e da preparaçáo para um conhecimento de mercado, fartas de uma universidade que elimina o prazer do experimento e só coloniza as mentes e os corpos "para o patriarcado e seus saberes encaixotados, não para o saber e, muito menos, para a crítica às formas de saber”. E, ainda, um exercício para partilhar e sair da fantasia do sujeito autônomo que, no caso das faculdades de arte, traveste-se na sinistra e cansativa metáfora masculina do Gênio.]

Como vemos, o livro de Polanco mostra sua importância não apenas ao explicar de maneira sucinta os princípios da investigação artística hoje e sua relevância para um melhor entendimento do presente; ao escolher fazer isso por meio de uma crítica a uma antiga Bildung - eurocêntrica, burguesa, patriarcal e desenvolvida a partir de um retiro dos indivíduos de suas próprias sociedades - em favor de uma nova Bildung - o mais inclusiva possível e desenvolvida por meio de uma participação concreta dos indivíduos nos enfrentamentos das suas sociedades-, ela expande seu exame a toda a condição do pensamento universitário hoje. Com efeito, parece bastante claro que no ensino superior como um todo - e isso com certeza é válido para o ensino superior brasileiro - ainda prevalecem os efeitos da antiga Bildung, isto é, as "cores cinzas" de um saber por isolamento, introspecção e abstração, um saber que, por sinal, tende a nos convencer da suposta estranheza e extravagância, para não dizer superfluidade e ineficácia, das "cores vivas" de 
um saber por coletividade, experiências práticas e conhecimentos tácitos. Dessa forma, é preciso notar que o livro de Polanco coloca-se, sobretudo, em uma importante vanguarda de pensamento: falar sobre investigação artística hoje não é simplesmente falar sobre uma prática acadêmica restrita às artes e às humanidades; é, a bem da verdade, colocar em xeque toda uma ortodoxia de pensamento acadêmico que se legitima não apenas pela longevidade da sua própria tradição, mas também, e talvez sobretudo, pelos benefícios que ela tende a garantir a um capitalismo cognitivo, isto é, ao desenvolvimento e à detenção do conhecimento como amparo, direto ou indireto, a alguma forma de lucro - muitas vezes alheio, quando não avesso, a um ideal mesmo de conhecimento.

\section{Referências}

ADORNO, Theodor. "The Essay as Form”. Trad. Bob Hullot-Kentor; Frederic Will. New German Critique, n. 32, Durham, 1984, p. 151-71.

BENJAMIN, Walter, The Arcades Project. Trad. Howard Eiland; Kevin McLaughlin. Cambridge: Belknap, 1999.

POLANCO, Aurora Fernández. Crítica Visual del Saber Solitario. Bilbao: Consonni, 2019

POLANCO, Aurora Fernández. "Escribir desde el Montaje: Otra Forma de Exponer". In: BLASCO, Selina (ed.). Investigación Artística y Universidad: Materiales para un Debate. Madrid: Ediciones Asimétricas, 2013, p. 105-16.

POLANCO, Aurora Fernández. "Lectores de Signos, Lectores de Guińos: el Ensayo Curatorial como Forma". In: WECHSLER, Diana (ed.). Pensar con Imágenes. Buenos Aires: Editorial de la Universidad Nacional de Tres de Febrero, 2015, p. 91-111.

Fábio Waki. Bacharel em Estudos Literários (2012) e Mestre em Linguística / Estudos Clássicos (2015) pela Universidade Estadual de Campinas. É atualmente estudante de doutoramento em Materialidades da Literatura na Universidade de Coimbra (2016).

E-mail: fabwaki@gmail.com 